\title{
BETONARME SONLU ELEMAN ANALİZINDE ALTERNATİF BİR KOHEZİF ÇATLAK MODELİ
}

\author{
Efe SELMAN \\ İzmir Ekonomi Üniversitesi, Mühendislik Fakültesi, İnşaat Mühendisliği Bölümü, 35330, İzmir, TÜRKİYE \\ efe.selman@ieu.edu.tr
}

(Geliş/Received: 10.08.2020; Kabul/Accepted in Revised Form: 14.01.2021)

ÖZ: Beton yapıların hasar değerlendirmelerinde, çatlak yüzeylerindeki kohezif etkileşimi göz önüne alan modeller, güvenilir ve gerçekçi simülasyonlara olanak tanımışlardır. Kohezif modeller, çatlak arayüzeylerinde, çatlak açılma ve kohezif kapanma gerilmeleri arasındaki dengeyi, betonun çekme yumuşaması özelliği ile birlikte göz önüne almaktadır. Bu çalışma, bu kohezif yaklaşımdan kaynaklanarak, kohezif etkileşimin çatlak yüzeylerinde betonun çekme yumuşaması davranışına göre tanımlandığı bir sonlu eleman modeli geliştirmiştir. Nümerik analizler için ABAQUS programı kullanılmıştır. Sunulan kohezif esaslı modelin etkinliğini gösterme amaçlı, diğer simülasyon Genişletilmiş Sonlu Eleman Metodu'nu kullanarak gerçekleştirilmiş ve iki yaklaşımın sonuçları yapısal parametreler bazında karşılaştırılmıştır. İki yaklaşım sonuçları arasındaki yüksek uyum, sunulan kohezif çatlak yaklaşımının doğruluğunu kanıtlamıştır.

Anahtar Kelimeler: Çatlak, Kohezif etkileşim, Sonlu eleman

\section{An Alternative Cohesive Crack Model for Finite Element Analysis of Reinforced Concrete}

\begin{abstract}
In the damage evaluation of concrete structures, the models based on the cohesive interaction between crack surfaces enable reliable and realistic simulations. The cohesive models take into account the equilibrium between crack opening and cohesive closing stresses at crack interfaces with the tension softening property of concrete. This study stemmed from this cohesive approach and developed the finite element model with discrete crack approach in which the cohesive interaction was defined along crack surfaces according to the tension softening behaviour of concrete. ABAQUS program was used for numerical analysis. In order to demonstrate the efficiency of proposed cohesive based approach, the other simulation was conducted by using Extended Finite Element Method and results of these two approaches were compared according to the structural parameters. The good agreement between the results of two approaches proved the accuracy of the proposed cohesive crack approach.
\end{abstract}

Key Words: Crack, Cohesive interaction, Finite Element Method

\section{GİRIŞ (INTRODUCTION)}

Artan gerilmeler altında beton, kendi içerisinde oluşan mikro yapısal değişiklikler sebebiyle, kendine özgü bir mekanik davranış sergilemektedir. Doğrusal olmayan şekil değiştirme karakterinin yanında, yüksek basınç dayanımlarına karşılık düşük çekme dayanımında gevrek kırılma eğilimi göstermesi ve sünme etkileri, bu davranışı karmaşık hale getiren etmenlerden sayılabilir. Bu durumda, betondaki davranışı gerçekçi olarak tanımlayabilmek için, güç tükenmesi davranışı esnasında gelişecek hasar oluşumlarının nitel ve nicel olarak etkin bir şekilde değerlendirilmesi gerekliliği ön plana çıkmaktadır. 
Düşük çekme dayanımı sorumlu gevrek hasar gelişimi altında, mikroçatlakların oluşması ve çatlak yüzeylerinde oluşacak etkileşimin izin verdiği ölçüde bu oluşumların ilerleyip makro düzeye erişmesi, betonun güç tükenmesi davranışında başrolü oynamaktadır. Mikro düzeyden başlayarak çatlamanın başlaması ile, betonda çatlak noktalarında yerel gerilmelerde ani değişiklikler meydana gelmektedir. Bu değişikliklerin sorumlusu, çatlak yüzeylerinde çekme gerilmesinin aşılmasıyla ortaya çıan açılma gerilmeleri ile kohezif kapanma gerilmeleri arasındaki dengedir (Shi, 2009). Çatlak yüzeyindeki bu etkileşim, betonun mekanik davranışında ani bir şekil değiştirme yumuşaması ile gözlenmektedir. Bir başka deyişle, betonun çekme yumuşaması olarak bilinen bu olay, hasarın gelişmesini belirleyen en önemli noktalardan biridir (Shi, 2009). Çatlak yüzeylerindeki çatlak açılma ve kohezif kapanma gerilmeleri arasındaki denge, betonun çekme yumuşaması davranışı karakteri altında incelenmelidir (Shi, 2009).

Sonlu elemanlar yöntemi ile yürütülen çalışmalarda, mikroçatlak oluşumu, makrodüzeye ulaşması, ilerleme şekli ve betonun güç tükenmesi davranışına etkisi, direkt veya dolaylı yollarla modellenmektedir. Çatlak yapılarını modellemede kullanılan yaklaşımlar iki ana başlıkta toplanabilir. Bunlar, ayrık(discrete) ve yayılı(smeared) modellemelerdir (Akkaya, 2006; Maekawa ve diğ., 2003; Jendele ve diğ., 2001; De Borst ve diğ., 2004). Yayılı çatlak modeli, çatlak oluşumlarını dolaylı yoldan tarif etmeyi seçmiştir. Sonlu eleman geometrisinde çatlak lokasyonu ve geometrisi oluşturulmadan, dolaylı olarak, betonun çekme yumuşaması davranışı altında azalan rijitlik değerleri doğrultusunda betonun malzeme davranışı güncellenmektedir. Bir başka deyişle, çatlamış beton artık betondan farklı bir mekanik davranışa sahiptir (Maekawa ve diğ., 2003; Jendele ve diğ., 2001; De Borst ve diğ., 2004). Yayılı modeller, yapıların genel davranışlarının ve parametrelerinin incelenmesinde sıklıkla kullanılmaktadır. Bu yaklaşımın en önemli avantajı, sonlu elemanlar metodu kapsamında çözümlemelerde yaşanacak olan çatlak lokasyonlarındaki süreksizliklerin yaratabileceği yakınsaklık sorunlarını çözmesidir (Maekawa ve diğ., 2003). Fakat yapı sisteminin yerel olarak çatlak bölgesindeki davranışı araştırılıyorsa ve çatlak karakteri tanımlanmak isteniyorsa, ayrık(discrete) modellemeler tercih edilmektedir. Ayrık modellemelerde, sonlu eleman modelinde çatlak lokasyonu ve ilerlemesi, geometriye yansıtılır. Çözümlemelerde çatlak geometrisinin direkt olarak göz önüne alınması sebebiyle, çatlak yönelim ve etkileşimleri etkin bir şekilde elde edilebilmektedir (Akkaya, 2006; Maekawa ve diğ., 2003; Jendele ve diğ., 2001; De Borst ve diğ., 2004).

$\mathrm{Bu}$ çalışma kapsamında çatlak oluşumlarının geometrisi bazında mekanik davranışları, doğruluk derecesi yüksek bir şekilde simüle edilmesi amaçlanmış ve bu doğrultuda yerel çatlak arayüzeylerinde çatlak oluşum ve gelişim tanımlamaları yapılacağından, ayrık yaklaşım benimsenmiştir. Literatürde ayrık ve yayılı tekniği karşılaştıran, uygulamalardaki etkinliğini tartışan birçok çalı̧̧ma mevcuttur (Shi, 2009; Maekawa ve diğ., 2003). Her ne kadar hem ayrık hem de yayılı çatlak modellemeleri yaklaşımları sıklıkla kullanılsa da, hasar nitelik ve niceliğini belirlemeyi hedefleyen çalışmalarda ayrık teknik, doğası gereği, bu süreçte daha çok tercih edilmiş ve irdelenmiştir (Maekawa ve diğ., 2003).

İlk kez kohezif kapanma kuvvetlerini, Dugdale (Shi,2009; Maekawa ve diğ., 2003) çatlak plastik bölgenin ucundaki maksimum plastik gerilme değerine göre üniform olarak değişen kuvvetler cinsinden ifade etmiştir. Kohezif kuvvet ve çatlak ucundaki çekme gerilmelerinin birbiri içinde dengesi üzerine geliştirilen bu ilk metodoloji, ayrık teknikle çatlak tanımlamaların hareket noktası olmuştur (Maekawa ve diğ., 2003). Hillerborg (Shi,2009; Hillerborg ve diğ., 1976), Dugdale'nin ham modelini geliştirerek ve betonda çekme yumuşaması davranışı altında çatlak açılma ve kohezif kapanma gerilmeleri dengesini anlatarak Fiktif Çatlak Modeli'ni geliştirmiştir (Shi, 2009). Bu model, günümüz ayrık teknik yaklaşımının temel felsefesini oluşturmaktadır (Shi, 2009). Son yıllarda bir sürü çalışmalar öne çıkmış olsa da, bu çalışmanın temel aldığı en öne çıkan araştırmalar; Saloustros ve arkadaşları (Saloustros ve diğ., 2015), Dias da Costa ve arkadaşları (Dias da Costa ve diğ., 2018) ve Pham ve arkadaşları (Pham ve diğ., 2018)'nın yaptıklarıdır. Bu çalışmalarda, betonda çatlak arayüzeylerinde artan gerilme altında gelişen normal ve teğetsel gerilme ilişkileri, arayüzey rijitliğiyle tanımlanmış ve sonlu eleman modellerine yansıtılmıştır. Böylelikle çatlak ilerlerken hem arayüzey davranışı eş zamanlı olarak kontrol edilmiş, hem de hasar gelişiminin yapısal sistemin rijitliğine olan etkisi daha etkin bir şekilde 
izlenebilmiştir (Saloustros ve diğ., 2015; Dias da Costa ve di $\breve{g}$., 2018; Pham ve diğ., 2018). Bu modellerin ortak özelliği, çatlak arayüzey kohezif davranış esaslarını çekme yumuşaması davranışıyla anlatabilmeleridir. Bahsi geçen çalışmalar, arayüzey davranışa odaklanırken çekme-ayrılma davranışının mekaniğinin en yalın örneklerinden olan delaminasyon olgusunu seçmişlerdir (Saloustros ve diğ., 2015; Dias da Costa ve diğ., 2018; Pham ve diğ., 2018). Pham ve arkadaşları'nın çalışması bir adım öne çıkarak, arayüzey davranışında hasar gelişimini asal gerilme matrisiyle açıklamıştır. Bu durum, çekme yumuşaması davranışının üç eksenli olarak tanımlanmasını sağlamıştır (Pham ve diğ., 2018). Aynı felsefeyle benzer öne çıkan çalışmalar olarak Yun ve arkadaşları (Yun ve diğ., 2018), Nikolic ve arkadaşları (Nikolic ve diğ., 2018) ve Bhowmick ve Liu'nun çalışmaları (Bhowmick ve Liu, 2018) söylenebilir.

Bu makaledeki çalışmanın temel dayanağı Ors ve arkadaşları'nın yürüttükleri çalışma olmuştur (Ors ve diğg., 2014). Bu çalışmada Ors ve arkadaşları'nın (Ors ve diğg., 2014) çalışmasındaki anlayışa paralel şekilde, yayılı ve ayrık yaklaşım teknikleri belli anlamda birleştirilerek kullanılmış, yapı mekaniği bağlamında gerçekçi sonuçlar elde edilmiştir. Fakat bu çalışmanın mevcut literatürden ayrıldığı nokta veya bir diğer deyişle bu çalışmanın can alıcı yanı, önceden belirlenmiş çatlak lokasyonlarındaki arayüzeylerde kohezif etkileşim tanımlanmış, bunun yanı sıra yayılı teknikten baz alınarak betonun çekme yumuşaması altında azalan rijitliği göz önüne alınarak, gerilme-şekil değiştirme davranışı düzenlenip beton mekanik özelliklerine aktarılmıştır.

Genişletilmiş Sonlu Elemanlar Metodu (XFEM) ile irdelenen çatlak oluşumu ve ilerleme analizleri, yüksek güvenilirlikleri ile sıklıkla tercih edilmektedir (Maekawa ve diğ., 2003; Patil ve diğ., 2019; Pommmier ve diğ., 2011). Bu çalışmada, çalışmanın önerdiği ayrık yaklaşım felsefesini karşılaştırma amaçlı XFEM'den yararlanılmıştır. XFEM yaklaşımı, en yüzeysel tanımıyla dislokasyon veya çatlak noktalarında yeni düğüm noktaları oluşturarak gerilme şiddeti faktörleri(K)'ni çatlak oluşum kriterleri açısından değerlendirip, dış etkiler altında çatlak ilerlemesini sunmaktadır. XFEM detaylarına Teorik altyapı bölümünde değinilmiştir. Bu çalışmaya temel olan XFEM çalışmaları Patil ve arkadaşları (Patil ve diğ., 2019) ve Dirik ve Yalçınkaya (Dirik ve Yalçınkaya, 2018)'nın çalışmalarıdır. Bu çalışmalarda XFEM teorik altyapısı anlaşılır ve betonda çatlak ilerlemesi incelemelerine uyarlanabilir bir şekilde anlatılmaktadır.

Belirtilen esaslarca bu çalışmanın temel amacı, çatlak yüzeylerindeki mikro düzeydeki etkileşimi tanımlayarak, incelenen yapısal elemanın davranışını makro düzeyde doğru değerlendirebilmektir. Daha teknik açıdan tanımlanmak istenirse, çatlak arayüzeylerindeki kohezif etkileşimi, beton çekme yumuşaması başlığı altında modellemek ve bu hasar gelişim modeli yardımıyla genel olarak yapısal sistemin karakterini irdelemektir. Bu amaç doğrultusunda çalışmanın akışı oluşturulmuştur. Giriş bölümünü; ayrık modelin temelini oluşturan çatlak mekaniği, betonun çekme yumuşaması ve bu çalışmada önerilen metodun karşılaştırılması için kullanılan XFEM esaslarını özet bir şekilde anlatan teorik bölüm izlemektedir. Üçüncü bölümde modelleme esasları verildikten sonra, dördüncü bölümde bu araştırmada sunulan kohezif modelleme yaklaşımının sonuçları XFEM sonuçları ile karşılaştırılmış, bulgular değerlendirilmiştir. Son bölümde ise genel sonuçlar sunulmuştur.

\section{TEORİK ALTYAPI (THEORETICAL BACKGROUND)}

Betonda en gelişmiş çatlak mekaniği modellerinin başında Fiktif Çatlak Modeli gelmektedir (Shi, 2009; Hillerborg ve diğ., 1976). Günümüzde de birçok model, bu modelden türemiş olup farklı uygulama alanlarında denenmiştir (Jendele ve diğ., 2001; De Borst ve diğg., 2004). Şekil 1'de olayın şematize hali görülmektedir. " $w_{c}$ " mevcut çatlağın genişliği olmak üzere, " $w$ " fiktif çatlak genişliği, " $\sigma(w)$ " çekme yumuşama bölgesi gerilme-şekil değiştirme ilişkisi, " $\mathrm{f}_{\mathrm{t}}$ " betonun çekme dayanımı ve " $\mathrm{K}$ " ise gerilme şiddeti faktörünü göstermektedir. Bu modelin ana ilkesi, artan gerilme altında köprüleşme bölgesinde çatlak yüzeylerinde oluşan çatlak açılma gerilmeleri ile kohezif bölgede oluşan kohezif kapanma gerilmeleri arasındaki dengeye bağlıdır. Çatlağın ilerlemesi için çatlak açılma gerilmelerinin kohezif kapanma gerilmelerini yenmesi gerekmekte, sonrasında ise köprüleşme bölgesinin çekme yumuşaması davranışı göstermesi beklenmektedir. 
Çekme yumuşaması, çekme dayanımının aşılması ile mikroçatlamanın başlaması ve çatlak genişliğinin artmasını gösteren ilişkidir. Şekil 2'de " $\mathrm{f}_{\mathrm{t}}=\mathrm{f}_{\mathrm{ct}}$ " ç̧ekme dayanımını göstermek üzere, " $\mathrm{E}_{\mathrm{t}}$ " betonun çekme elastisite modülü, denklem (1) ile ifade edilen " $\mathrm{wtu}$ " çatlak açılma deplasmanını ve denklem (2) ile (Shi, 2009; Hillerborg ve diğ., 1976) tarafından önerildiği üzere "Gfu" ise çekme yumuşaması altında kalan alan olan kırılma enerjisini göstermektedir. Denklem 2' de " $\mathrm{d}^{\prime}$ " maksimum agrega çapını ve " $\mathrm{f}_{\mathrm{c}}$ " ise betonun karakteristik basınç dayanımını göstermektedir. Şekil 2' de ayrıca C25 betonu için bu modelin uygulanmış hali de genel modelin yanında sunulmuştur.

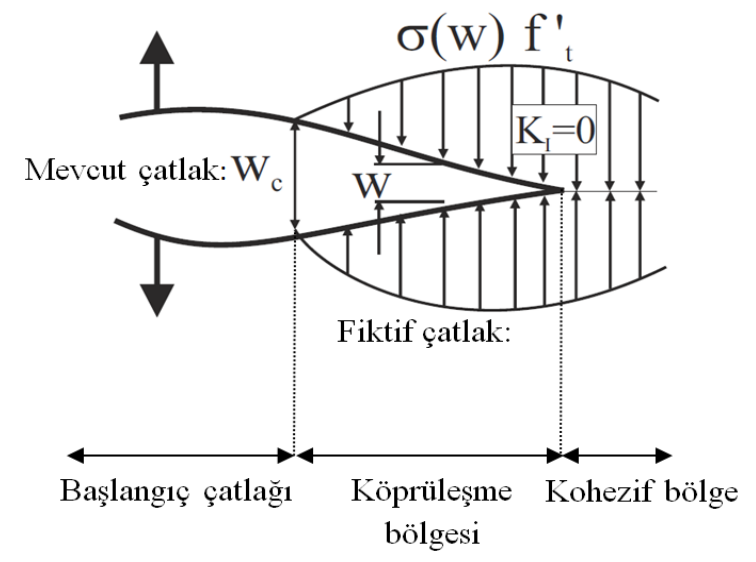

Şekil 1. Betonda Fiktif Çatlak Modeli'nin şematize gösterimi (Shi, 2009)

Figure 1. Schematic representation of Fictitious Crack Model in concrete (Shi, 2009)

$w_{t u}=\frac{18 G_{F}}{5 f_{c t}}$

$G_{f}=\left[10^{-3}\left(0.0469 d_{a}^{2}-0.5 d_{a}+26\right)\right]\left(\frac{f_{c}}{10}\right)^{0.7}$

Çekme yumuşaması, köprüleşme bölgesinde tanımlanırken bir diğer husus, çatlağın çok modlu doğası gereği yüzeylerinde oluşacak teğetsel gerilmelerin de varlığıdır. Fakat bu gerilmeler çalışmada sunulacak kohezif modelleme tekniği ile sonlu eleman programına dahil edilmiştir. Çalışma kapsamında ABAQUS programı kullanılmıştır (Abaqus, 2018). Teğetsel gerilmeler çatlak kayma deplasmanını getirmektedir. Çatlak ilerleme profili, çatlak açılma deplasmanları ve çatlak kayma deplasmanlarının sisteme adaptasyonu ile belirlenmektedir. Çekme yumuşamasına benzer şekilde, geçmiş çalışmalarda teğetsel gerilmelerle çatlak kayma deplasmanlarını ilişkilendiren modeller mevcuttur (Shi, 2009; Maekawa ve diğ., 2003; Saloustros ve diğ., 2015; Ors ve diğg., 2014). Fakat Modelleme bölümünde anlatılacağı üzere, çalışma kapsamında çekme yumuşaması davranışının gerçekçi olarak yansıtılabilmesi için, çekme yumuşaması, ABAQUS (Abaqus, 2018) sonlu eleman programında birebir olarak kohezif etkileşimde tanımlanmıştır. Programın çekme yumuşaması altında kohezif ara yüzeyin üç boyutlu deforme olmuş şeklini hesaba katmasıla oluşan teğetsel gerilmeler altındaki kayma deplasmanları da böylelikle göz önüne alınmış olunmaktadır. 

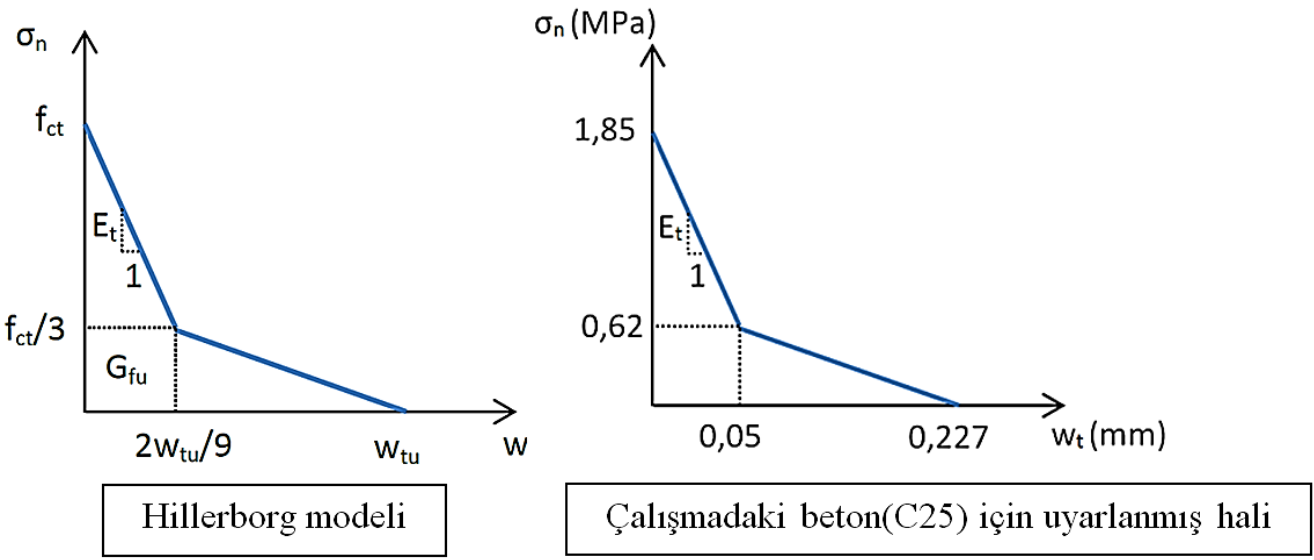

Şekil 2. Betonda çekme yumuşaması davranışı ve uygulanması (Shi, 2009)

Figure 2. Tension softening in concrete and application (Shi, 2009)

Çatlak ilerlemesini modelleyen bir başka etkili modül ise Genişletilmiş Sonlu Elemanlar Metodu(Extended Finite Element Method-XFEM) yaklaşımıdır (Pommier ve diğ., 2011). Bu yaklaşım, temel olarak deforme olmuş çatlak yüzeylerinde komşu bağlı noktalar arasındaki düzensizliklerin çözümüne olanak tanımaktadır. Temel mantı̆̆ı, çatlak ucundaki kuvvetlerin dengesi prensibi ile, kohezyon kuvvetlerini gerilme şiddeti faktöründen (K) yararlanarak hesaplama üzerine kuruludur (Pommier ve diğ., 2011). Gerilme şiddeti faktörü(K), her modda çatlak ucu etrafındaki gerilme dağılımı fonksiyonunu göstermektedir. Her çatlakta lokal bazda bağımsız olarak çalışması sebebi ile çatlama kriterini ifade etmede sıklıkla tercih edilmektedir. Çatlak yüzeyindeki çekme gerilmesi ve kohezif kapanma gerilmesi dağılımlarının dengesi, çatlağın ilerlemesinde belirleyici rol oynamaktadır. XFEM(Genişletilmiş Sonlu Elemanlar Metodu) tanımlaması ve yer değiştirme vektörüne ulaşması en temel anlamda (3) nolu denklemle açıklanabilir (Pommier ve dĭ̆., 2011). " $\Gamma$ " modeldeki düğüm noktalarını göstermek üzere, " $\Gamma_{\mathrm{t}}$ " ve " $\Gamma_{\mathrm{c}}$ " sırasıyla çatlak yüzü ve ucundaki dügüum noktalarını

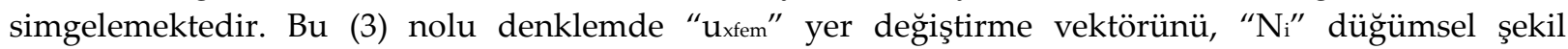
fonksiyonunu, " $u_{i}$ " zenginleştirilmemiş düğüm noktaları için düğümsel yer değiştirme vektörünü göstermektedir. Zenginleştirme fonksiyonu olarak " $\mathrm{H}(\mathrm{x})$ " ile gösterilen Heaviside fonksiyonu kullanılmaktadır. "ai", Heaviside fonksiyonu ile ilgili düğümsel zenginleştirilmiş serbestlik derecesi vektörü, " $\mathrm{F}_{\mathrm{a}}(\mathrm{x})$ " asimptotik çatlak ucu fonksiyonu ve " $\mathrm{b}_{\mathrm{a}} \mathrm{a}^{\text {" }}$ ise çatlak ucu zenginleştirmesi ile ilgili düğümsel zenginleştirilmiş serbestlik derecesi vektörünü göstermektedir (Pommier ve diğ., 2011; Islam ve diğ., 2017)

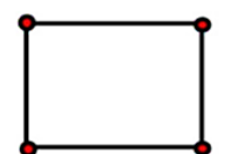

(Hasars1z)

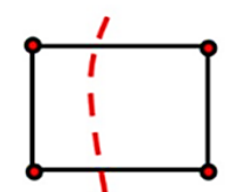

(Hasarın başlaması)

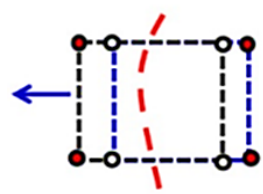

(Hasar gelişimi)
- Orijinal sonlu eleman noktaları

- Zenginleştirme fonksiyonu ile elde edilen sonlu eleman noktaları

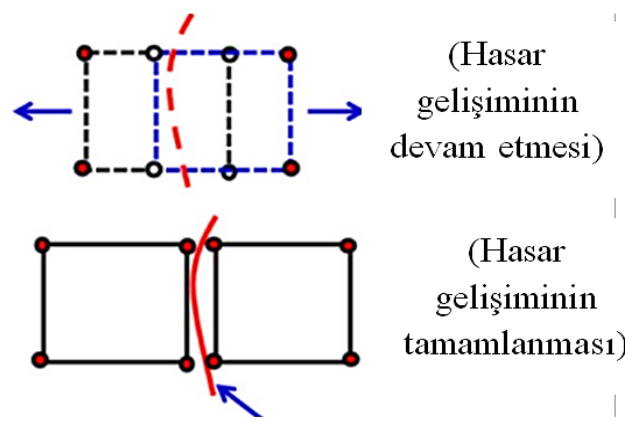

Şekil 3. XFEM tekniğinin şematik olarak açıklanması (Islam ve diğ., 2017) Figure 3. Schematic explanation of XFEM technique (Islam et al.., 2017) 


$$
u_{x f e m}=\sum_{i \varepsilon \Gamma} N_{i}(x)\left(u_{i}\right)+\sum_{i \varepsilon \Gamma_{c}} N_{i}(x) H(x)\left(a_{i}\right)+\sum_{i \varepsilon \Gamma_{t}}\left[N_{i}(x) \sum_{a=1}^{4} F_{a}(x) b_{i}^{a}\right]
$$

XFEM, Şekil 3'te şematize edildiği üzere çatlak ilerlemesi sırasında zenginleştirme fonksiyonlarından yararlanarak çatlak lokasyon ve yönelimini tarif edecek yeni dügüm noktaları oluşturur. Bu yeni ve orijinal noktalara eklenen düğüm noktaları sayesinde gelişen çatlak geometrisi elde edilebilmektedir. Çatlak geometrisinde böylelikle gerilme şiddeti faktörü(K), hesaplanabilecek, çatlak yüzeylerinde gerilme dağılımı incelenebilecek ve olası çatlak ilerleme analizleri yapılabilinecektir. Şekil 3 yöntemin çalışma şeklini somut bir şekilde aktarmaktadır (Islam ve dĭ̆., 2017).

\section{MODELLEME (MODELLING)}

Çalışmada sonlu eleman modelleme kapsamında kullanılan program, önceden de belirtildiği üzere ABAQUS (Abaqus, 2018) programı olup, Şekil 4'de bu programda hazırlanan sonlu eleman modeli gösterilmektedir. Çatlak davranışını inceleme amacıyla, bu kiriş elemanda ayrık(discrete) çatlak modelleme tekniğinden yola çıkılarak, Şekil 5'te de görüleceği üzere, yükleme altında ilk oluşan ana eğilme çatlağı geometrisi tam ortadan yüzeye dik olacak şekilde idealize edilerek göz önüne alınmıştır. Çatlağın geometrisi, beton elemanın ortasındaki ayrık yüzeyde tanımlanmıştır. Şekil 6 ' da ise betonarme elemanın donatı konfigürasyonu ve geometrisi ayrıntılı biçimde sunulmuştur. Bu noktada ayrık yüzeyde çatlak yüzeylerindeki davranışı anlatabilme amacıyla, detayları bu bölümde anlatılacak, A1 ve A2 isimleriyle kodlanmıs, iki farklı modelleme yaklaşımından yararlanılmıştır.

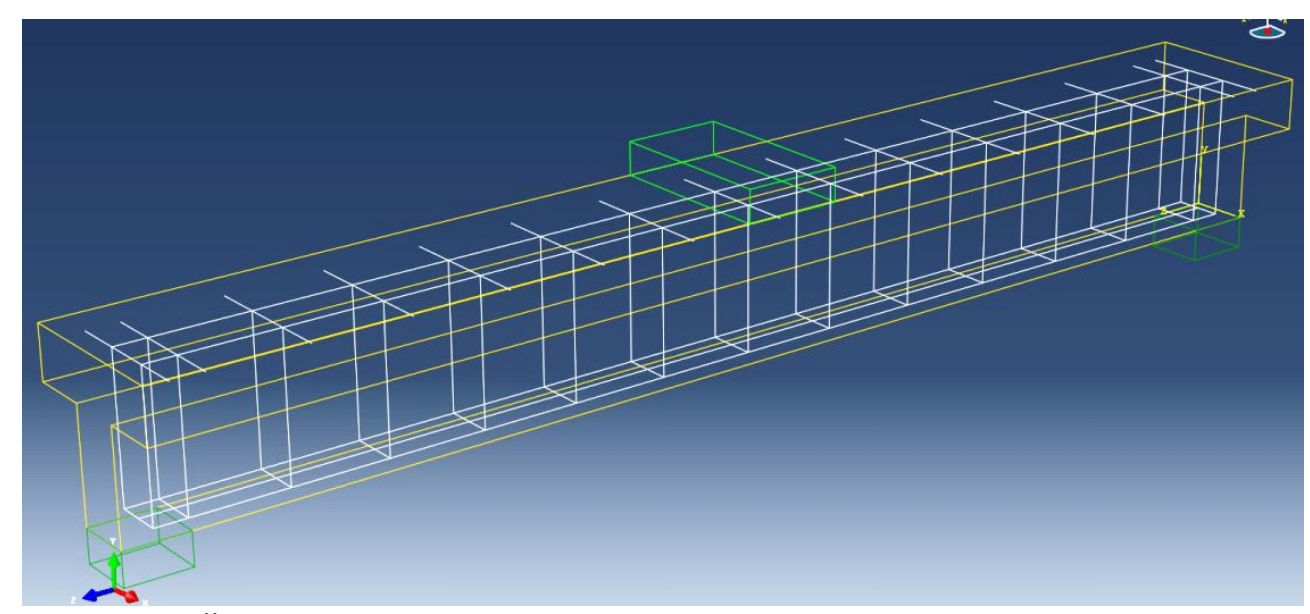

Şekil 4. Üç boyutlu ABAQUS betonarme modelinin gösterimi (Abaqus, 2018)

Figure 4. Representation of the $3 d$ ABAQUS reinforced concrete model (Abaqus., 2018)

Tahmin edileceği üzere, Şekil 4'te sarı renkle görülen sonlu eleman betonarme eleman, yeşil renkle görülen eleman ise çelik rijit levhalardır. Beyaz renkli çubuk elemanlar ise boyuna donatı ve etriyeleri simgelemektedir. Deney düzeneği kapsamında basit kiriş mesnet şartlarını oluşturacak şekilde, başlangıç ve bitiş noktalarında sınır şartları belirlenmiştir. Bu sınır şartları, çözümlemelerde olası bir sonlu eleman yakınsaklık sorunu yaşanmaması için iki adet rijit olarak tanımlanan $100 * 50 * 300 \mathrm{~mm}$ (En*Boy*Açıklık) boyutlarında çelik bloğa verilmiş olup, bu çelik bloklarla elemanın bağlantısı ABAQUS (Abaqus, 2018) programında "Tie(Bağ)" ile sağlanmıştır. Yükleme için de aynı tekniğe başvurulmuş olup, yükleme levhası da sınır şartları levhaları ile özdeş çelik rijit blokla tanımlanmıştır. Yükleme levhası ile eleman da yine aynı şekilde "Tie(Bağ)" ile bağlanarak birlikte çalışması sağlanmıştır. Çelik rijit blokların malzeme mekanik özellikleri, program kapsamında sadece elastik özellikleri girilmiş olup, bu değerler; yoğunluk " $\gamma$ ", $\gamma=7.85 \mathrm{~g} / \mathrm{cm}^{3}$, Elastisite modülü " $E$ ", E= $210000 \mathrm{MPa}$ ve Poisson oranı "v", $\nu=0.3$ olarak dikkate alınmıştır. Bulgular kısmında da belirtildiği ve değerlendirildiği üzere, modellerin yük-orta nokta deplasman grafikleri analiz kapsamında elemanın deplasman kontrollü analizi yürütülmüş ve gerekli irdelemeler yapılmıştır. 


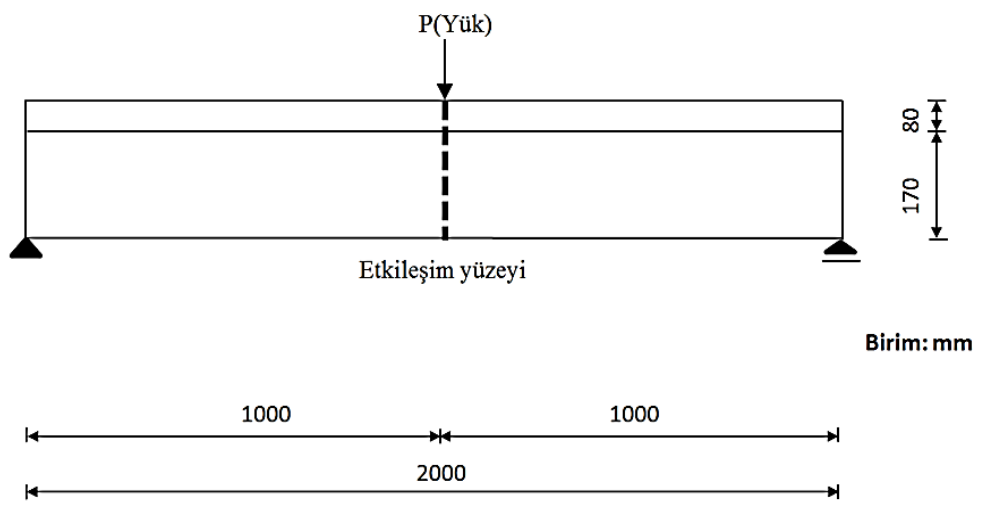

Şekil 5. Betonarme elemanın geometrisi ve çatlak etkileşim yüzeyi Figure 5. Geometry of reinforced concrete model and crack interaction surface

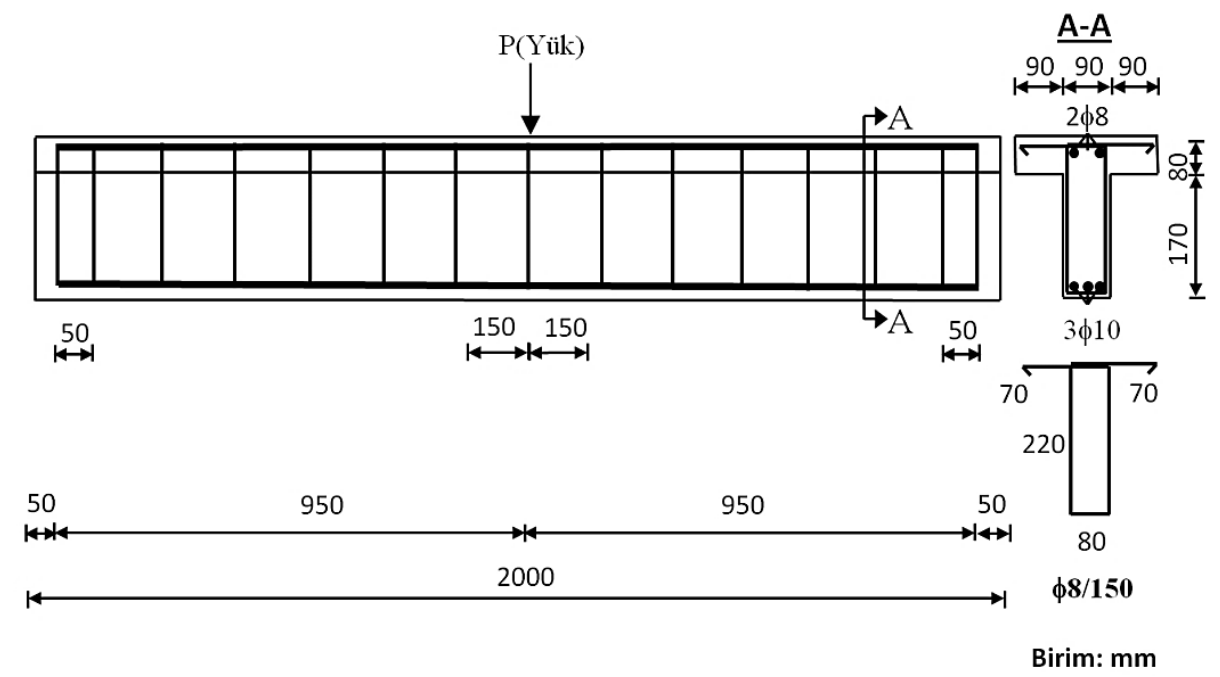

Şekil 6. Betonarme elemanın geometrisi ve donatı konfigürasyonu Figure 6. Geometry and rebar configuration of reinforced concrete model

Modelleme çalışmaları kapsamında beton eleman, katı eleman(solid) C3D8R sonlu eleman türünde modellenmiştir. C3D8R elemanı, sekiz dügüum noktasına ve bir integrasyon noktasına sahip lineer üç boyutlu hekzahedral sonlu eleman ağ modelidir. Kullanılan teknik modül ise Beton Hasarlı Plastisite (Concrete Damaged Plasticity-CDP)'dir (Abaqus, 2018). Bu modül gerilme şekil değiştirme ilişkilerinin akma yüzeyi ile desteklendiği betonu oldukça iyi açıklayan bir tanımlama yöntemidir. Çizelge 1'de CDP tekniği kapsamında girilen malzeme sınıfı C25 olan betonun modüle işlenen temel mekanik parametreleri listelenmiştir.

Çalışma kapsamında seçilen beton modeli basınç davranışı için betonun güç tükenmesini özellikle en büyük dayanım noktasından sonra gerçekçi bir şekilde tanımlayan Mander-Priestley-Park modelidir (Mander ve diğ., 1988). Şekil 6'dan da görüldügüü üzere sargısız beton için birim şekil değiştirme $\varepsilon_{c o}=$ $0.002 \mathrm{~mm} / \mathrm{mm}$ değerinde beton nihai basınç dayanımına ulaşmaktadır. Bu değerden sonra dayanımı azalışa geçen beton, $\varepsilon_{\varepsilon}=0.0035 \mathrm{~mm} / \mathrm{mm}^{\prime}$ de yaklaşı bu değerin iki katı olan birim deformasyon değerinde göçme kapasitesine ulaşmaktadır. Dayanımın sıfır olduğu nokta ise birim şekil değiştirme $\varepsilon_{c}=$ $0.005 \mathrm{~mm} / \mathrm{mm}$ değeridir. (4) nolu formülde de görüldüğü üzere herhangi bir andaki basinç gerilmesi değerine " $\mathrm{f}_{\mathrm{c}}$ ", kuşaltılmış beton basınç dayanımının " " ve " $\mathrm{r}$ " oranları ile ilişkilendirilerek ulaşılmaktadır. " $x$ " oranı (5) nolu denklemde açıklandığı üzere betonun " $f_{c}$ " dayanımında iken sahip olduğu birim deformasyon " $\varepsilon_{c}$ " 'nin, " $\varepsilon_{c c}$ " ile gösterilen kuşatılmış beton basınç dayanımına karşılık gelen birim deformasyona oranıdır. " $\mathrm{r}$ " ise beton elastisite modülü " $\mathrm{E}_{\mathrm{c}}$ " 'nin, beton elastisite modülü "Ec" ile sekant elastisite modülü olan "Esec" farkına oranıdır. " $r$ " oranı (6) nolu denklem ile 
tanımlanmıştır (Mander ve diğ., 1988). Hiç şüphesiz, modelleme kapsamında sargısız beton modeli kullanılmıştır. Burada sargılı veya başka bir deyişle kuşatılmış beton davranış ilişkilerinin de gösterilme sebebi konu bütünlüğünün bozulmaması adınadır.

Çizelge 1. Beton için CDP modelinde kullanılan malzeme parametreleri Table 1. Material parameters used in the CDP model for concrete

\begin{tabular}{|c|c|}
\hline CDP Parametreleri & \\
\hline Yoğunluk $(\gamma)\left(\mathrm{g} / \mathrm{cm}^{3}\right)$ & 2,5 \\
\hline $\begin{array}{l}\text { Elastisite modülü } \\
\left(E_{c}\right)(\mathrm{MPa})\end{array}$ & 32500 \\
\hline Poisson oranı $(v)$ & 0,2 \\
\hline Dilatasyon açısı $(\Phi)$ & $30^{\circ}$ \\
\hline $\begin{array}{l}\text { Başlangıç plastik } \\
\text { basınç dayanımı }\left(\mathrm{f}_{\mathrm{pci}}\right) \\
\text { (MPa) }\end{array}$ & 15,4 \\
\hline $\begin{array}{l}\text { Karakteristik basınç } \\
\text { dayanımı }\left(\mathrm{f}_{\mathrm{c}}\right)(\mathrm{MPa})\end{array}$ & 25 \\
\hline $\begin{array}{l}\text { Çekme dayanımı }\left(\mathrm{f}_{t}\right) \\
\text { (MPa) }\end{array}$ & 1,85 \\
\hline $\begin{array}{l}\text { İki eksenli/tek } \\
\text { eksenli basınç birim } \\
\text { şekildeğiştirme oranı } \\
\text { (६) }\end{array}$ & 1,6 \\
\hline 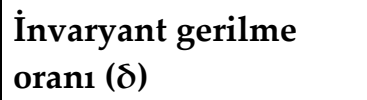 & 0,6667 \\
\hline
\end{tabular}

$$
f_{c}=\frac{f_{c c}^{\prime} x \cdot r}{r-1+x^{r}}
$$

$x=\frac{\varepsilon_{c}}{\varepsilon_{c c}}$

$r=\frac{E_{c}}{E_{c}-E_{\mathrm{sec}}}$

$\varepsilon_{c c}=\varepsilon_{c o}\left[1+5 .\left(\frac{f_{c c}^{\prime}}{f_{c 0}^{\prime}}-1\right)\right]$

${f^{\prime}}^{\prime}{ }_{c c}={f^{\prime}}^{\prime}\left[-1,254+2,254 \cdot \sqrt{1+\frac{7,94 \cdot f_{l}^{\prime}}{f_{c 0}^{\prime}}}-2 \frac{f_{l}^{\prime}}{f_{c 0}^{\prime}}\right]$ 


$$
E_{s e c}=\frac{f_{c c}^{\prime}}{\varepsilon_{c c}}
$$

Kuşatılmış beton basınç dayanımına karşılık gelen birim deformasyon " $\varepsilon$ cc" bulunması için model (7) nolu ilişkiyi önermektedir. Bu formülizasyonda " $\mathrm{f}$ 'co" sargılanmamış beton basınç dayanımını gösterirken, " $\varepsilon_{\mathrm{co}}$ " ise kuşatılmamış betonda tasarım mukavemetinde birim şekil değiştirme değeri olan 0.002'ye karşıllk gelmektedir. Beton sekant elastisite modülü "Esec" ve kuşatılmış beton dayanımını (f'cc) bulmada kullanılan bağıntılar (8) ve (9) nolu denklemlerde verilmektedir. (9) nolu denklemde görüldüğü üzere, " $\mathrm{f}^{\prime} \mathrm{cc}^{\prime}$ ", kuşatılmamış beton basınç dayanımı olan " $\mathrm{f}$ ' co" ve kuşatılmış çekirdek beton etkin yanal kuşatma gerilmesi olan "f'ı" ile ilişkilendirilmiştir (Mander ve diğ., 1988) (4) no.'ludan (9) no.'lu denkleme kadar olan seri göz önüne alınarak, Şekil 7'deki sargısız beton modeli basınç gerilmebirim şekil değiştirme ilişkisi verilmiştir.

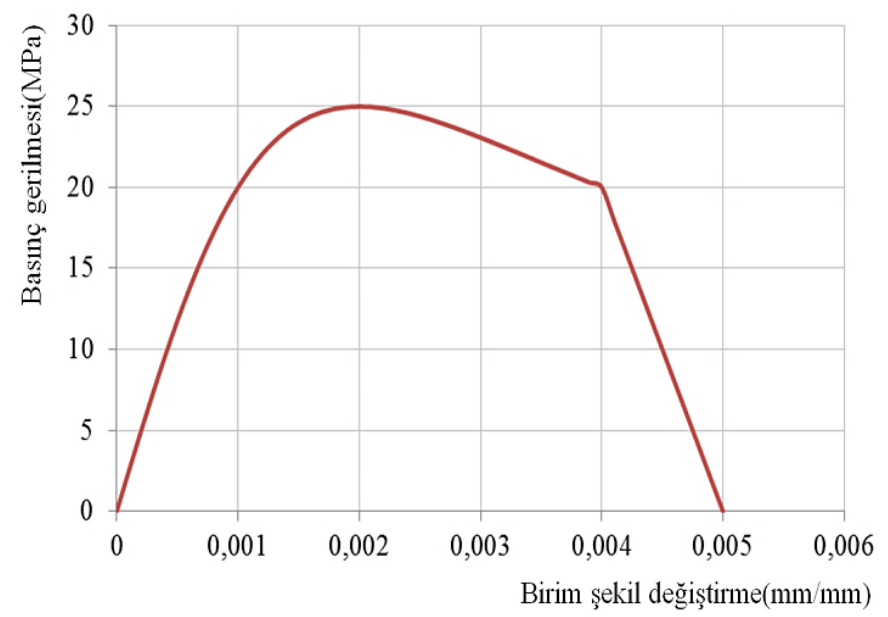

Şekil 7. Betonun Mander- Priestley- Park beton modelince basınç gerilmesi-birim şekil değiştirme modeli (Mander ve diğ., 1988)

Figure 7. The compressive stress-strain behavior of concrete according to Mander-Priestley-Park concrete model (Mander et al..,1988)

Betonun çekme davranışı için Chang-Mander beton modeli seçilmiştir (Chang ve Mander, 1994). Çekme gerilmesi-şekil değiştirme ilişkisi için, (10), (11) ve (12) nolu bağıntılarda " $\mathrm{ft}_{\mathrm{t}}$ " incelenen noktada çekme kuvvetini ve " $\mathrm{f}_{\mathrm{t}}$ " çekme dayanımını gösterirken $\mathrm{n}$ ve $\mathrm{x}$ oransal büyüklükler (11) ve (12)'de gösterilmektedir." $r$ " katsayısı ise şekil faktörü olup literatürde $r=4$ değerinin doğru sonuçlar vermesi nedeni ile önerildiği notlara eklenmiştir (Tort ve Hajjar, 2004). (11) ve (12) nolu bağıntılardaki "Et" betonun çekme elastisite modülü, " $\mathrm{f}$ 'co" sargılanmamış beton basınç dayanımını, " $\varepsilon \mathrm{t}$ " incelenen noktada çekme gerilmesine karşılık gelen birim şekil değiştirme, " $\varepsilon_{\mathrm{tt}}$ " çekme dayanımına karşılık gelen birim şekil değiştirmeyi göstermektedir. (10), (11) ve (12) nolu denklemler esas alınarak betonun çekme gerilme-birim şekil değiştirme ilişkisi Şekil 8'de olduğu gibi elde edilmiştir.

$$
\begin{aligned}
& f_{t}=f^{\prime}{ }_{t} \frac{n x}{1+\left(n-\frac{r}{r-1}\right) \cdot x+\frac{x^{r}}{r-1}} \\
& n=\frac{E_{t} f_{c 0}^{\prime}}{f^{\prime}{ }^{\prime}}
\end{aligned}
$$


$x=\frac{\varepsilon_{t}}{\varepsilon_{t t}}$

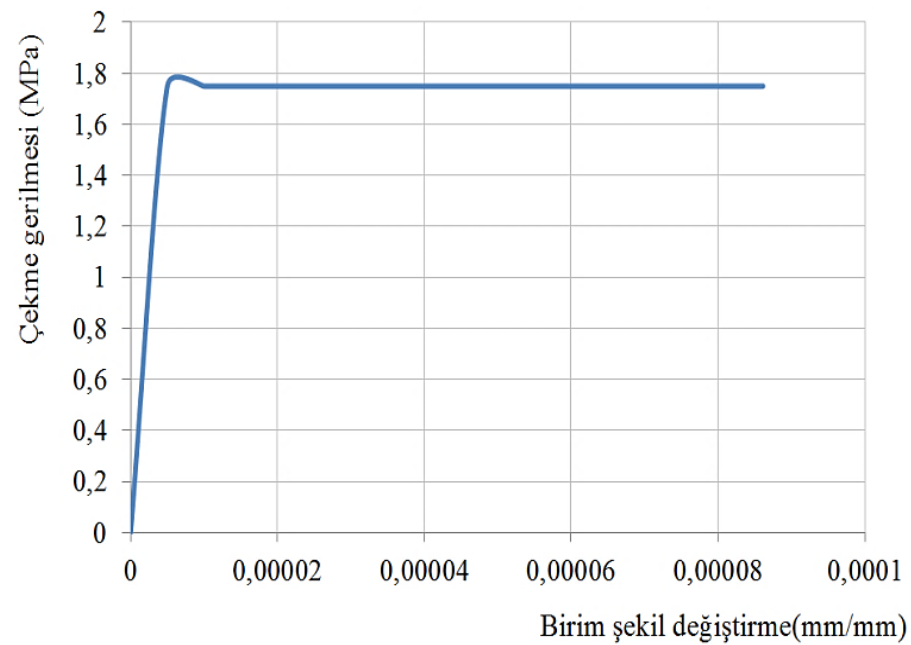

Şekil 8. Betonun Chang- Mander beton modelince çekme gerilmesi-birim şekil değiştirme modeli (Chang ve Mander, 1994)

Figure 8. The tensile stress-strain behavior of concrete according to Chang-Mander concrete model (Chang and Mander, 1994)

Çalışma kapsamında donatı çeliği modeli olarak, basınç ve çekme altında, elastoplastik Chang ve Mander (Chang ve Mander, 1994) donatı çeliği modeli kullanılmıştır. Model, (13), (14) ve (15) denklemleriyle özetlenmiştir. Bu ilişkilerde bahsi geçen parametreler, sırasıyla, " $\mathrm{f}_{\mathrm{s}}$ " donatı çeliğindeki gerilme, "Es" donatı çeliğinin elastisite modülü, " $\varepsilon_{s}$ " donatı çeliğinin birim şekil değiştirmesi, " $\mathrm{fs}_{\mathrm{sy}}$ " donatı çeliğindeki akma dayanımı, " $\varepsilon_{s y}$ " donatı çeliğinin akma birim şekil değiştirmesi, "fsu" donatı çeliğindeki kopma dayanımı, " $\varepsilon_{s u}$ " donatı çeliğinin kopma birim şekil değiştirmesi, " $\varepsilon_{s h}$ " donatı çeliğinin pekleşme başlangıcındaki birim şekil değiştirmesini simgelemektedir. Bu modele göre, donatı çeliğinin akma gerilmesine kadar gerilme birim şekil değiştirme ilişkisi çeliğin elastisite modülünce lineer olarak oluşturulmaktadır. Akma gerilmesinde şekil değiştirme " $\varepsilon_{s y}$ " 'den " $\varepsilon_{s h}$ " 'ye kadar ötelenmektedir. " $\varepsilon_{s h}$ " 'den sonra pekleşmenin etkisiyle dayanım, kopma birim şekil değiştirmesi olan " $\varepsilon$ su" "ya kadar artarak " $\mathrm{f}_{\text {su" }}$ kopma dayanımına kadar çıkmaktadır. B420C donatı çeliği için TBDY 2018' de de önerildiği üzere $\varepsilon_{\mathrm{sy}}=0,002 \mathrm{~mm} / \mathrm{mm}, \varepsilon_{\mathrm{sh}}=0,0075 \mathrm{~mm} / \mathrm{mm}, \varepsilon_{\mathrm{su}}=0,12 \mathrm{~mm} / \mathrm{mm}$ ve $\mathrm{f}_{\mathrm{su}}=550 \mathrm{MPa}$ olarak belirtilmiştir. Şekil 9'da donatı çeliğinin basınç ve çekme gerilme-birim şekil değiştirme davranışı grafikte özetlenmiştir. Çeliğin elastik malzeme parametreleri, sırasıyla, Elastisite modülü, "Es", $E_{s}=210000 \mathrm{MPa}$ ve Poisson oranı, " $v$ ", $v=0,3$ alınmıştır.

$$
\begin{aligned}
& f_{s}=E_{s} \cdot \varepsilon_{s}, \quad \varepsilon_{s}<\varepsilon_{s y} \\
& f_{s}=f_{s y}, \quad \varepsilon_{s y} \leq \varepsilon_{s} \leq \varepsilon_{s h} \\
& f_{s}=f_{s u}-\left(f_{s u}-f_{s y}\right) \frac{\left(\varepsilon_{s u}-\varepsilon_{s}\right)^{2}}{\left(\varepsilon_{s u}-\varepsilon_{s h}\right)^{2}}, \varepsilon_{s}>\varepsilon_{s h}
\end{aligned}
$$

Çalışma dahilinde, yükleme altında beton ve donatının birlikte çalışabilmesi için bir başka deyişle beton-donatı aderansı, Gömülü eleman(embedded) tekniği ile modellemeye yansıtılmıştır. Bu tekniğe göre betondaki düğüm noktaları ev sahibi (host) bölge, donatıdaki noktalar ise gömülü bölge (embedded) olarak belirlenmiştir. 


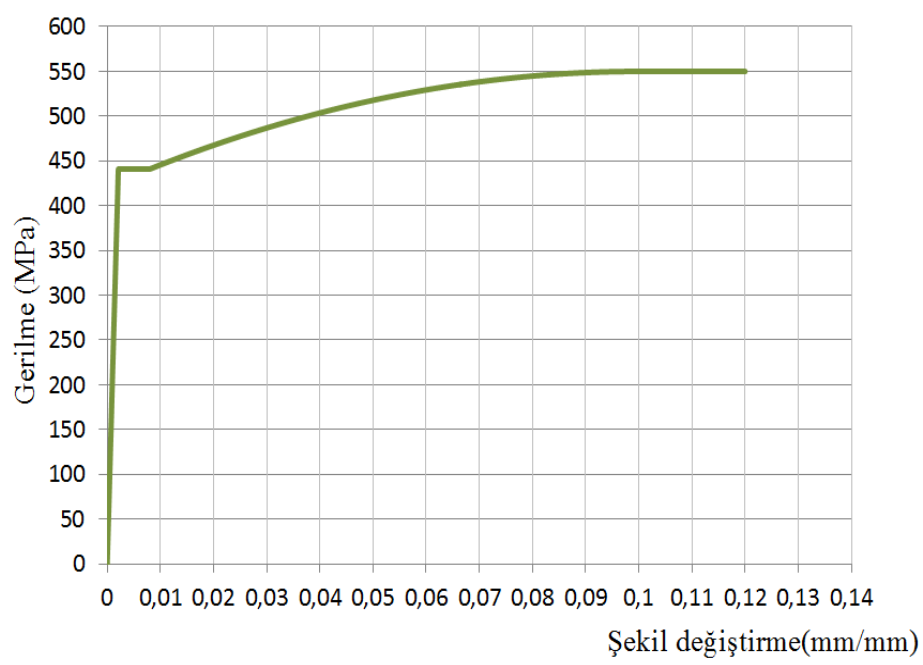

Şekil 9. Donatı çeliğinin Chang- Mander çelik modelince gerilme-birim şekil değiştirme modeli (Chang ve Mander, 1994)

Figure 9. The stress-strain behavior of steel reinforcement according to Chang-Mander steel model (Chang and Mander, 1994)

Modellemeler kapsamında A1 modeli yaklaşımı başlı̆̆ı altında çatlak etkileşim yüzeyinde ABAQUS(Abaqus, 2018) programında yüzeyler arası etkileşim(Interaction/surface to surface contact) tekniği seçilmiş ve burada yüzey bazında çatlak ilerleme özellikleri belirlenmiştir. Etkileşim bazında yararlanılan iki modül bulunmaktadır. Bu modüller, Hasar(Damage) ve Kohezif davranış (Cohesive behavior) modülleridir. Burada birebir anlamda amaçlanan Fiktif Çatlak Modeli esaslı çatlak yüzeylerindeki çatlak açılma ve kohezif kapanma kuvvetleri dengesine dayanan modeli tanımlayabilmektir. Şekil 2'de tanımlanan çekme yumuşaması altında çatlak açılma deplasmanı ve takibinde gelişen kayma gecikmesi esaslı çatlak yüzeyleri kayma deplasmanı davranışları bu modüllere aşağıda anlatılacağı üzere yansıtılmıştır. Hasar(Damage) modülü kapsamında başlangıç çatlak oluşumu kriteri yine Şekil 2'de görülmek üzere C25 beton sınıfı özelliklerince çekme için "fot"=1.85 MPa, kayma için " $\mathrm{s}_{\mathrm{s}}$ " $=0.95 \mathrm{MPa}$ ve kırılma enerjisi " $\mathrm{G}$ " $=0.11 \mathrm{~N} / \mathrm{mm}$ olarak tanımlanmıştır. Kayma için belirlenen kriterle teğetsel gerilmelerin çatlak kayma deplasmanına etkisi göz önüne alınmıştır. Kayma dayanımı kriteri, Shi(Shi, 2009)'nin özdeş yükleme altındaki aynı boyutlu kirişlerde yürütülen üç noktalı eğilme deneylerinden yola çıkılarak yaklaşık olarak çekme dayanımının yarısı olarak değer aldığı belirtilmiştir. Zaten literatürdeki birçok modelde çatlak arayüzeylerindeki kayma gerilmesi-çatlak kayma deplasmanı ilişkisi için deneysel çalışmaların yardımıyla kayma dayanımı kriteri, çekme dayanımının yarısı olarak önerilmektedir (Shi, 2009; Maekawa ve diğ., 2003; Bhowmick ve Liu, 2018). Bu kayma dayanımı değerinden sonra çatlak kayma deplasmanı yapmaya başlamaktadır. Bu önerinin kullanılma sebebi, kayma deplasmanı adına pratik çıkarımlar yapabilmek adınadır. Kırılma enerjisi ise yine özdeş yükleme altında ve aynı boyutlu kirişle Shi(Shi,2009)'nin yaptığı üç noktalı eğilme deneylerinde ölçülen "Gf"=0.11 $\mathrm{N} / \mathrm{mm}$ değeridir. Hasar modülünde deplasman değerleri bazında ise Şekil 2'deki çekme yumuşaması davranışındaki gerilmeye karşılık gelen çatlak açılma miktarları girilmiştir.

A1 yaklaşımının ikinci kolu olan "Kohezif davranış" modülü kapsamında ise Şekil 2'deki çekme yumuşaması başlangıç rijitlik değerleri girilmesi planlanmaktadır. Bu modülde betonun çekme ayrılma ilişkisi "Hasar" modülü kısmında tanımlandığı için ayrıca bir rijitlik değeri girilmeden, yüzeyler arası kohezif davranışı betimleme amaçlı, programa girilen çekme-ayrılma(traction-separation) ilişkisinden yararlanarak, eksenel rijitlik değeri olan "Knn", sırasıyla düzlem içi ve düzlem dışı kayma rijitlik değerleri olan "Kss" ve "Ktt" rijitlik değerlerini programın kendisinin hesaplamasına olanak tanıyan mevcut seçenek "default" işaretlenmiştir. Bu sayede, çatlak gelişimi altında, arayüzey rijitlik değerlerini programın kendisinin güncellemesi sağlanmıştır. Çatlak kayma deplasmanı yüzeylerde değerlendirilmiş olup, deforme olmuş çatlak profil geometrisine yansıtılmıştır. 
A2 yaklaşımı ise birebir anlamda XFEM tekniği kullanılarak hazırlanmıştır. XFEM tekniği kapsamında çatlak geometrisi ayrı bir tek eksenli eleman (wire) olarak katı(solid) eleman üzerine yerleştirilmiştir. Daha sonra bu geometride etkileşim başlı̆̆ 1 altında programda otomatik tanımlı çatlak ataması yapılmıştır. Çatlak geometrisine atanan etkileşim XFEM olarak belirlenmiş ve takibinde " $\mathrm{q}$ " vektörü ile çatlak doğrultusu önceden gösterilmiştir. Teorik yaklaşımı Teorik Altyapı kısmında anlatılan XFEM tekniği böylelikle birebir olarak program tarafından sisteme uygulanmıştır. XFEM tekniğinin kullanılma sebebi, çalışma kapsamında sunulan A1 yaklaşımının geçerliliğini değerlendirebilmek amacıyladır. XFEM tekniği(Pommier ve diğ., 2011) önceden de belirtildiği üzere, çatlak oluşumu ve ilerleme mekanizmalarını başarıyla gösteren etkili bir tekniktir.

\section{BULGULAR ve TARTIŞMA (FINDINGS and DISCUSSION)}

Önceden de belirtildiği üzere, çalışma kapsamında değerlendirilen sonlu eleman modelinin orta noktasında bulunan çatlağın modellenmesinde A1 ve A2 olmak üzere iki farklı yaklaşım değerlendirilmiştir. Bu doğrultuda sistemin yapısal davranışının belirlenmesinde Şekil 10'da görülen yük(kN)-orta nokta deplasman(mm) eğrileri karşılaştırılmıştır. Şekil 10'da kırmızı eğriyle gösterilen A0 yaklaşımında herhangi bir çatlak oluşturulmamış elemanın kusursuz olduğu varsayılmıştır. A1 ve A2 yaklaşımları ayrık(discrete) tekniğe dayanan yaklaşımlar olup kısaca tanımlamalarıyla hatırlatılmak istenirse, A1 kohezif davranışla çatlak tanımlayı seçen metod iken, A2 yaklaşımı XFEM modülünü kullanan yaklaşımdır. Beklenildiği üzere A0 çatlak konfigürasyonu içermemesi sebebiyle A1 ve A2'nin üzerinde kalarak, yük olarak en yüksek yaklaşık 38 kN'a kadar çıkarken daha sonra yaklaşık $6 \mathrm{kN}$ civarına düşerek nihai noktada $0,35 \mathrm{~mm}$ deplasman yapmıştır. Çatlağın oluşturulması ile yük taşıma kapasitesi ve orta nokta deplasman değeri düşmektedir. Fakat A1 ve A2 yaklaşımları ile elde edilen eğrilerin tutarlılı̆̆ 1 oldukça iyi seviyededir. A1 en büyük yük taşıma kapasitesini 27,2 kN olarak belirlerken A2 bu değeri 30,3 kN olarak belirlemiştir. Daha dikkat çekici olan nokta nihai deplasmanlar neredeyse çakışmış olup A1'de 0,305 mm olan bu değer A2' de 0,301 mm olarak elde edilmiştir. A1 ve A2 yaklaşımları ile elde edilen diğer yük-deplasman değer serileri de, eğri şekilleri birbirleri ile karşılaştırıldığında oldukça yakın olduğu görülmektedir.

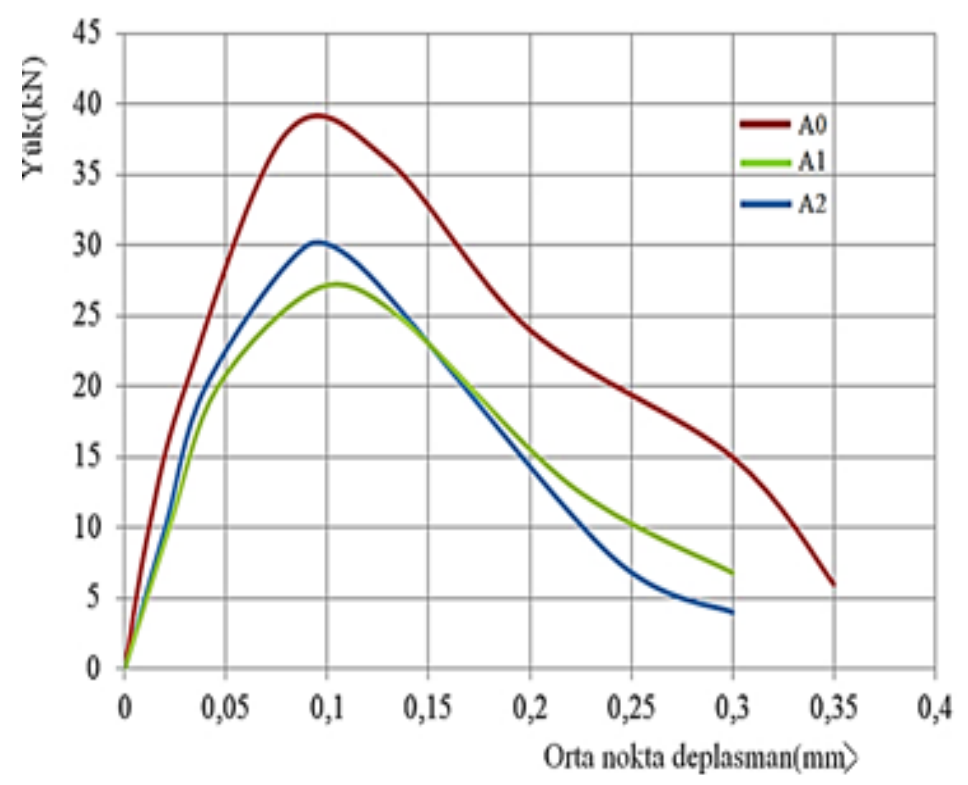

Şekil 10. Sonlu eleman modellerinin yük $(\mathrm{kN})$-orta nokta deplasman(mm) eğrileri

Figure 10. The load $(k N)$-mid. displacement curves of finite element models

Şekil 11'de ise A1 ve A2 yaklaşımlarıyla elde edilen çatlak ağzı açılma deplasmanları(crack mouth opening displacement -CMOD) ilgili yük seviyelerinde karşılaştırılmıştır. Çatlak ağzı açılma 
deplasmanı, çatlağın başlangıç bölgesindeki genişliğidir. Eğrilerin karakterinden de anlaşılacağı üzere, özellikle maksimum yüke kadar neredeyse birebir örtüşen davranışlarla karşılaşılmıştır. A1 yaklaşımı, kohezif davranış esasları gereğiyle modellendiğinden, maksimum yükü $(27,2 \mathrm{kN})$, XFEM tekniğine göre hazırlanan A2 yaklaşımının belirlediği yüke $(30,3 \mathrm{kN})$ göre biraz daha az belirlemiş ve bu noktadan sonra eğriler arasında değersel olarak belli bir fark gözlense de, eğrinin şekilsel karakteri değerlendirildiğinde, nihai çatlak ağzı açılma deplasmanına kadar yumuşama davranışı iki yaklaşım sonuçlarınca da benzer şekilde devam etmiştir. A1 yaklaşımı nihai çatlak ağzı açılma deplasmanını 0,25 $\mathrm{mm}$ belirlerken, A2 bu değere yeteri yakınlıkta olup $0,22 \mathrm{~mm}$ olarak göstermiştir.

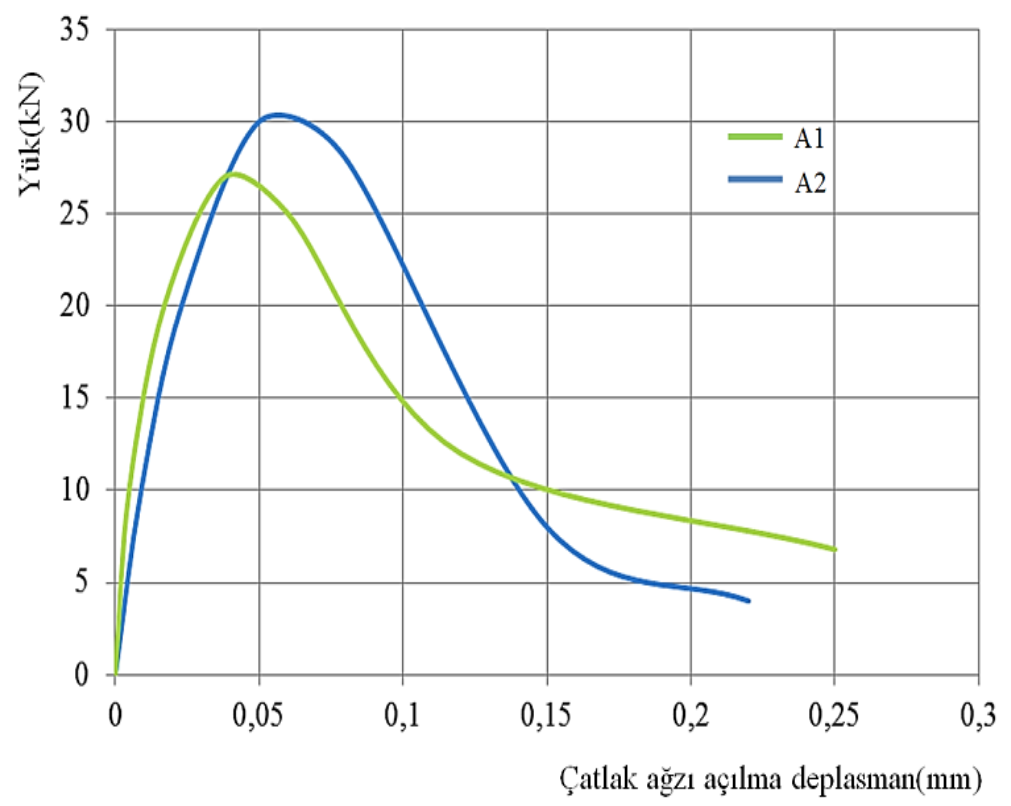

Şekil 11. Sonlu eleman modellerinin yük(kN)-çatlak ağzı açılma deplasman(mm) eğrileri Figure 11. The load $(\mathrm{kN})$-crack mouth opening displacement(CMOD,mm) curves of finite element models

Şekil 12'de ise karşılaştırılmalı olarak A1 ve A2 yaklaşımlarıyla elde edilen elemanın nihai şekil değiştirme kapasitesinde elde edilen çatlak profilleri ve Von Mises gerilme dağılımları ile sunulmuştur. Değerlendirme için, elemanda çatlağın bulunduğu bölge olan açıklığın ortasındaki $20^{*} 40 \mathrm{~cm}$ 'lik bölgeye yaklaşılmıştır. Yakınlaşılan bölge dışındaki gerilme dağılımları eşdeğer olarak gözlenmiştir. İki yaklaşımda da çatlak profillerinin deforme olmuş çatlak yüzeyleri açısından çok benzer olması dikkat çekicidir. Gerilme dağılımlarında ise her ne kadar çatlak yüzeylerindeki dağılımlar değersel ve dağılımsal açıdan benzerlik gösterse de, çatlak komşuluğundaki bölgede veya diğer bir deyişle açılığın ortasındaki $40 \mathrm{~cm}$ 'lik bölgede küçük bir farklılık görülmektedir. Fakat bu farklılık, yöntemlerin doğasından kaynaklanmaktadır. Kohezif yaklaşım olan A1'de, etkileşim yüzeyinin boylu boyunca tanımlanması, etkileşim yüzeyi boyunca göreli olarak daha yüksek Von Mises gerilme değerlerinin kümelenmesine sebep olmuştur. XFEM ile çözüm yapan A2 yaklaşımı ise ortada birim çatlak tanımlaması ile yola çıktığından, gerilme dağılımı sadece çatlak geometrisi boyunca yığılmamış, A1 yaklaşımına göre biraz daha eleman üst bölgesine yayılmıştır. Ama bu değerlerin Von Mises değerleri olduğunun altı çizilmelidir. Bunun yanısıra, çalışma kapsamında çatlak davranışını sonlu eleman dilinde ayrıntılı betimlemek adına, kiriş elemanda sadece ilk oluşacak eğilme çatlağı modellenmiştir. Eğilme çatlağının başlangıç ve köprüleşme bölgesindeki gerilme dağılımlarının iki yöntemle de birbirine çok yakın olarak gözlendiği vurgulanmalıdır. Artan yükleme altında oluşacak diğer çatlak ve çatlak yüzeylerinin tanımlanmasıyla, bütün elemanın gerilme dağılımı açısından iki yöntem sonuçları arasında birebir özdeşlik kurulacağı düşünülmektedir. 


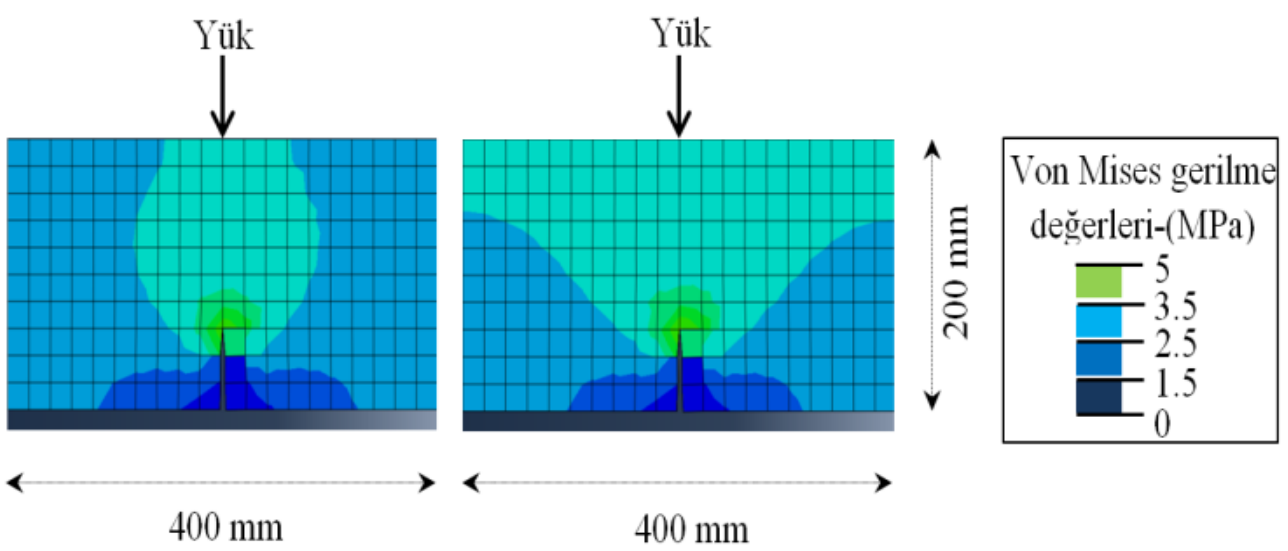

(A1)

(A2)

Şekil 12. Sonlu eleman modellerinin orta nokta çatlak profillerinin karşılaştırılması

Figure 12. Comparison of midpoint crack profiles of finite element models

\section{SONUÇ (CONCLUSION)}

Dış etkiler altında betonda gelişmekte olan hasarın tanımlanmasında çatlak oluşumlarının gerçekçi olarak modellenmesi kuşkusuz oldukça önemlidir. Elemanların yapısal performanslarının değerlendirilmesi ancak hasarın doğru bir nitel ve nicel değerlendirme süzgecinden geçirilmesiyle mümkündür. Son yıllarda bu alandaki sonlu eleman çalışmaları daha çok ayrık tekniği benimsemiş ve çatlak yüzeylerindeki çatlağın ilerlemesinden sorumlu olan çatlak açılma ve kohezif kapanma gerilmeleri dengesini esas alan alternatif modeller üretmiştir. Bu anlayış, kohezif davranış yaklaşımının bir anlamda hammaddesidir.

Bu çalışma, belirtilen esaslardan yola çıkarak, çatlak oluşumunu alternatif bir şekilde sonlu eleman metodolojisinde çatlak yüzeylerindeki kohezif davranış çerçevesinde anlatmayı amaçlamıştır. Örnek olarak üç noktalı eğilme deneyi altında basit kiriş eleman seçilmiştir. Elemanın A0, A1 ve A2 adlı üç farklı sonlu eleman modeli ABAQUS programında hazırlanmıştır. A0 çatlak oluşumunun gözönüne alınmadığı karşılaştırma modeliyken, A1 ve A2 modellerinde çatlak oluşumu, ayrık teknik esas alınarak eleman geometrisinde oluşturulmuştur. Çalışma kabulleri kapsamında sadece eleman açıklığının ortasında ilk oluşan eğilme çatlağ geometrisi idealize edilerek sisteme adapte edilmiştir. Çalışmanın önerdiği A1 modeli kohezif davranış prensibi ile oluşturulmuştur. A1 modelinde çatlak geometrisi boyunca arayüzey etkileşimi(interaction) oluşturulmuştur. Bu arayüzey kapsamında kullanılan modüller, "Hasar" ve "Kohezif" davranış modülleri olup bu kısımda çatlak oluşum kriteri ve betonun çekme yumuşaması davranışı girilmiştir. A2 modeli ise tipik bir XFEM uygulama örneği olup, çalışma kapsamında önerilen A1 modeli sonuçlarını yorumlama ve değerlendirme adına hazırlanmıştır.

A1 ve A2 model sonuçlarının yük-deplasman ve yük-çatlak ağzı açılma deplasmanlarının çok yakın olması, bunun yanısıra iki yöntemin de sunduğu nihai çatlak profillerinin çakışması, A1 modelinde kullanılan yaklaşımın, XFEM tekniğine kuvvetli bir alternatif olabileceğini kanıtlamaktadır. Bu bağlamda çalışmada sunulan A1 yaklaşımının en önemli yanının, çatlak davranışını anlatırken, betonun çekme yumuşamasındaki karakterini, birebir olarak çatlak arayüzeyindeki kohezif davranışa indirgemesi olduğu vurgulanmalıdır. Her ne kadar çatlak profillerinin etrafındaki gerilme dağılımında farklılıklar gözlense de çoklu çatlak tanımlaması ile bunun aşılacağı düşünülmektedir.

İleride bu alanda yapılan araştırmalar için düşünülen noktalar, çalışmada önerilen arayüzey kohezif davranış yaklaşımı göz önüne alınarak, çoklu çatlak tanımlaması yapılan elemanların çözülmesi ve daha sonra çoklu çatlak etkileşimlerinin yine aynı yaklaşımla incelenmesidir. 


\section{KAYNAKLAR (REFERENCES)}

ABAQUS, 2018, Version 6.14 User Manual, Hibbitt, Karlsson and Sorensen Incorporation, Powtucket, Rhode Island, A.B.D.

Akkaya, Y., 2006, Düzlem Gerilme Altında Betonarme Elemanların Doğrusal Olmayan Davranışının Sonlu Eleman Yöntemiyle İncelenmesi, Doktora Tezi, İstanbul Teknik Üniversitesi, Fen Bilimleri Enstitüsü, İstanbul.

Bhowmick, S., Liu, G. R., 2018, “A phase-field modeling for brittle fracture and crack propagation based on the cell-based smoothed finite element method", Engineering Fracture Mechanics, Cilt 204, ss. 369-387.

Chang, G.A., Mander, J.B., 1994, Seismic energy based fatigue damage analysis of bridge columns: Part I Evaluation of seismic capacity, State University of New York, NCEER Teknik Raporu, 43-61, A.B.D.

De Borst, R., Remmers, J. J. C., Needleman, A., Abellan, M. A., 2004, “Discrete and smeared crack models for concrete fracture: bridging the gap", International Journal for Numerical and Analytical Methods in Geomechanics, Cilt 28, No 7-8, ss. 583-607.

Dias da Costa, D., Graça e Costa, R., Ranzi, G., Smith, S.T., 2018, “Assessment of the behavior FRPstrengthened RC slabs using a discrete crack model", Journal of Composites for Construction, Cilt 22, No 6, ss. 1-14.

Dirik, H., Yalçınkaya, T., 2018, "Crack path and life prediction under mixed mode cyclic variable amplitude loading through XFEM", International Journal of Fatigue, Cilt 114, ss. 34-50.

Hillerborg, A., Moder, M., Peterson, P.E, 1976, "Analysis of crack formation and crack growth in concrete by means of fracture mechanics and finite elements", Cement and Concrete Research, Cilt 6, ss. 773-782.

Islam, M. R., Vallejo, M. J., Tarefder, R.A., 2017, “Crack Propagation in Hot Mix Asphalt Overlay Using Extended Finite-Element Model", Journal of Materials in Civil Engineering, Cilt 29, Say1 5, ss. $162-$ 196.

Jendele, L., Cervenka, J., Saouma V., Pukl, R., “On the choice between discrete or smeared approach in practical structural FE analyses of concrete structures", Fourth International Conference on Analysis of Discontinuous Deformation, Glasgow, 234-248, 6-8 Haziran 2001.

Maekawa, K., Okamura, H., Pimanmas, A., 2003, Nonlinear Mechanics of Reinforced Concrete, Taylor\&Francis Press, New York, A.B.D.

Mander, J.B., Priestley, M.J.N., Park, R., 1988, “Theoretical stress-strain model of confined concrete”, Journal of Structural Engineering, Cilt 114, Sayı 8, ss. 1804-1826.

Nikolic, M., Do, X., İbrahimbegovic, A., Nikolic, Z., 2018, “Crack propagation in dynamics by embedded strong discontinuity approach: Enhanced solid versus discrete lattice model", Computer Methods in Applied Mechanics and Engineering, Cilt 340, ss. 480-499.

Ors, D., Okail, H., Zaher, A., 2014, "Modeling of shear deficient beams by the mixed smeared/discrete cracking approach", Housing and Building National Research Center Journal, Cilt 12., ss. 123-136.

Patil, R. U., Mishra, B. K., Singh, I. V., 2019, “A multiscale framework based on phase field method and XFEM to simulate fracture in highly heterogeneous materials", Theoretical and Applied Fracture Mechanics, Cilt 100., ss. 390-415.

Pham, D. C., Cui, X., Lua, J., Zhang, D., "A continuum damage description for a discrete crack modeling approach for delamination migration in composite laminates", AIAA/ASCE/AHS/ASC Structures: Structural Dynamics and Materials Conference, Florida, 1-13, 15 Haziran 2018.

Pommier, S., Gravouil, A., Combescure, A., Moës, N., 2011, Extended Finite Element Method for Crack Propagation, Wiley Publications, New Jersey, A.B.D.

Saloustros, S., Pelà, L., Cervera, M., 2015, “A crack-tracking technique for localized cohesive-frictional damage", Engineering Fracture Mechanics, Cilt 150, ss. 96-114.

Shi, Z., 2009, Crack Analysis in Structural Concrete: Theory and Applications, Butterworth and Heinemann Press, New York, A.B.D. 
TBDY, 2018, Türkiye Bina Deprem Yönetmeliği, T.C. Bayındırlık ve İskan Bakanlığı, Ankara.

Tort, C., Hajjar, J.F., 2004, "Damage assessment of rectangular concrete-filled steel tubes for performance-based design", Earthquake Spectra, Cilt 20, Say1 4, ss. 1317-1348.

Yun, K., Wang, Z., He, L., Liu, J., 2018, "A damage model based on the introduction of a crack direction parameter for FRP composites under quasi-static load", Composite Structures, Cilt 184, ss. 388399. 